\title{
Large-scale Social Restrictions and Public Community Activity Restriction Legal Policy to Decrease COVID-19 Infections Effectivity to Handling COVID-19 Pandemic
}

\author{
Arief Budiono ${ }^{1 *}$ (D), Ayesha Hendriana Ngestiningrum ${ }^{2}$ (D), Siti Nurani ${ }^{3}$, Rizka Rizka ${ }^{1}$ (D), Nunik Nurhayati ${ }^{1}$, \\ Siska Diana Sari ${ }^{4}$ iD, Fauzan Muhammadi ${ }^{5}$ iD, Rangga Jayanuarto ${ }^{6}$ \\ ${ }^{1}$ Departmetn of Law, Faculty of Law, Universitas Muhammadiyah Surakarta, Surakarta, Indonesia; ${ }^{2}$ Departmetn of Midwifery, \\ Politeknik Kesehatan Surabaya, Surabaya, Indonesia; ${ }^{3}$ Department of Law, Universitas Muhammadiyah Kupang, Kupang, \\ Indonesia; ${ }^{4}$ Department of Law, Universitas PGRI Madiun, Madiun, Indonesia; ${ }^{5}$ Department of Law, Universitas Ahmad Dahlan, \\ Yogyakarta, Indonesia; ${ }^{6}$ Department of Law, Universitas Muhammadiyah Bengkulu, Bengkulu, Indonesia
}

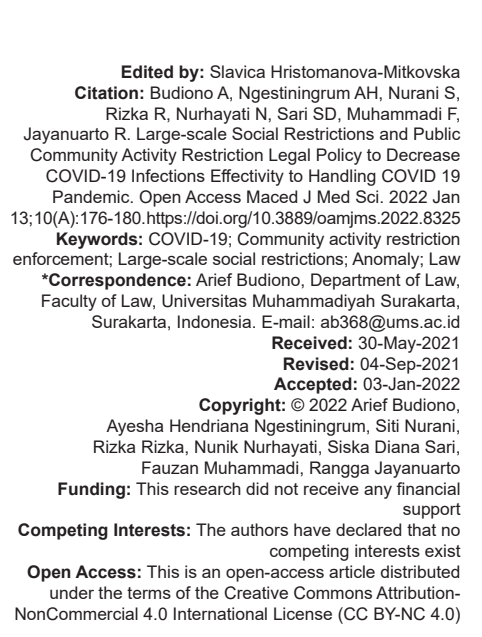

\begin{abstract}
The coronavirus disease 2019 (COVID-19) pandemic has caused a global impact. It also affected Indonesia. There had been tens of thousands of positive cases and thousands of deaths. Many paramedics also died to heal people from this disease. The Indonesian government determined this condition as a Social Emergency Condition and issued the Governmental Decree No. 21 of 2020 on Large-Scale Social Restrictions (LSSR) in 2020 (and Community Activity Restriction Enforcement [CARE] in 2021 with the Instruction of the Minister of Internal Affairs on Emergency CARE in Java and Bali islands). The Instruction of the Minister of Internal Affairs No. 15 of 2021 regulated the Application of the Emergency CARE due to the COVID-2019. In its implementation, the LSSR are ineffective in preventing the spread of the COVID-19 as there are some anomalies in the field, as this law is not strictly enforced. The spread of the COVID-19 becomes uncontrollable as there are no strict sanctions against violators of the LSSR. Meanwhile, the law-enforcing apparatus tend to ignore violations. This condition is different from the application of the CARE as it was more effective in decreasing the number of Covid-19 cases. This is because its implementation is equipped with supervision and strict sanctions. The strictness and the seriousness in applying the CARE yielded positive results, namely, the significant decrease of COVID-19 sufferers.
\end{abstract}

\section{Introduction}

The coronavirus disease 2019 (COVID-19) pandemic has caused a global impact. It also affected Indonesia. There had been tens of thousands of positive cases and thousands of deaths. Many paramedics also died to heal people from this disease. This pandemic affectedmanyaspects. Inthelegalaspect, thegovernment issued a packet of laws on March $31^{\text {st }}, 2020$ to handle this disease, namely the Governmental Regulation in lieu of Law No. 1 of 2020 on the State Financial Policy and Stability of the Financial System to Handle the Covid-19 Pandemic and/or to Face Dangerous Threats to the National Economy and/or Stability of the Financial System; the Governmental Decree No. 21 of 2020 on Large-Scale Social Restrictions (LSSR) to Accelerate the Handling of COVID-19; the Presidential Decision No. 11 of 2020 on the Determination of COVID-19 Social Health Emergency.
Various partial policies have been issued in the central and the provincial governments, such as the Decree of the Ministry of Education and Culture No. 4 of 2020 issued on March 24, on Implementation of Policies Amid the Emergency Condition of COVID-19 Pandemic that becomes the legal protection for the cancellation of the National Exam and learning from home. The Indonesian Police Force Issued the Head of the Police Force Notice No. Mak/2/III/2020 on the Compliance on the Governmental Policy to Handle the Spread of the Covid-19.

There are some polemics in the regulations to handle the Covid-19. For instance, the president signalized implementing LSSR and even civil emergency if necessary. Academics criticize the latter idea, as based on the Governmental Decree No. 23 of 1959 on the Revocation of Law No. 74 of 1957 on Emergency Condition Determination, authorities may confiscate items that are suspected to disturb security, wiretap phone conversations, and limit the use of communication tools. Academics regard this law to be 
more fitting to regulate anarchic conditions, as it may potentially be misused.

Then, the Governmental Regulation in lieu of Law No. 1 of 2020 is criticized as it focuses on economic risks without elaborating health-related strategies to handle the pandemic. Then, Article 27 of this regulation implementers of this law such as the Bank of Indonesia and Financial Service Authority officials cannot be sued if they undergo the task under good intentions and follow the law. This makes it difficult to uphold justice if officials are suspected to do criminal actions.

Next, the Governmental Decree No. 21 of 2020 on LSSR to Accelerate the Handling of the COVID-19 is also criticized. This decree should apply general-abstract norms based on the constitutional theory, but it has a concrete norm as it is equipped with the statement "to Accelerate the Handling of the COVID-19." Thus, this law cannot be used if new pandemics happen, which is exaggerating (overbodig) and inefficient. Then, its articles are far too simple (only containing seven articles) and it tends to only repeat the contents of Law No. 6/2018. Thus, based on the explanation above, the research problem is, "How is the anomaly of the enforcement of the LSSR law based on the Governmental Decree No. 21 of 2020 or the Community Activity Restriction Enforcement (CARE) implemented in 2021?"

\section{Methods}

This paper aims to describe the LSSR and the CARE policies amid the COVID-19 pandemic. It uses is a juridical approach with secondary data as the main source. It uses literature review to collect data by taking an inventory of various main and supporting literary materials relating to the focus of the problem, aiming to obtain a general and comprehensive description of the analyzed issue, namely, the government policies to prevent the massive spread of the COVID-19 pandemic.

\section{Results}

The great scale of the COVID-19 pandemic made the WHO General Director declare a Public Health Emergency of International Concern situation on January 30, 2020, based on International Health Regulations 2005. It warns states to prepare quarantine programs, active monitoring, early detection, etc. Responding to this, the Indonesian government treated COVID-19 positive patients, encouraging social distancing, limiting live animal imports from China based on the Ministry of Trade Decree No. 10/2020, and closing flights from
Table 1: Wilcoxon statistic test to all Java Bali [13]

\begin{tabular}{|c|c|c|c|}
\hline Alternative hypothesis & Statistic test & $p$-value & Conclusion \\
\hline H1: K2 July>K9 July & 7433 & 1 & No decrease of cases \\
\hline H1: K9 July>K16 July & 6298 & 1 & No decrease of cases \\
\hline H1: K16 July>K23 July & 4613 & 0.8759 & No decrease of cases \\
\hline H1: K23 July>K30 July & 3531 & 0.1 & No decrease of cases \\
\hline H1: K30 July>K6 Aug & 1238 & $3.173 \times 10^{-12}$ & The number of cases decreased \\
\hline$H 1: K 6 A u g>K 13$ Aug & 2431 & $2.736 \times 10^{-5}$ & The number of cases decreased \\
\hline$H 1: K 13$ Aug $>K 20$ Aug & 1100 & $4.992 \times 10^{-13}$ & The number of cases decreased \\
\hline$H 1: K 20$ Aug $>K 27$ Aug & 349 & $<2.2 \times 10^{-16}$ & The number of cases decreased \\
\hline
\end{tabular}

abroad. It also issued the Presidential Decree No. 11 of 2020 on the Determination of Covid-19 Social Health Emergency; the Governmental Decree No. 21 of 2020 on LSSR (GD No. 21/2020); the Decree of the Ministry of Health No. 9 of 2020 on LSSR Guidelines [1]; and other laws that regulate CARE in 2021.

The Instruction of the Minister of Internal Affairs No. 15 of 2021 regulated the Application of the Emergency CARE due to the COVID-2019 in Java and Bali. Hierarchically, it is based on the norms of Article 60 of Law No. 6 of 2018 on Health Quarantine (Law on Health Quarantine).

Table 2: Page statistics test per province [13]

\begin{tabular}{llll}
\hline Province & Statistic Test & p-value & Conclusion \\
\hline Banten & $1946^{* * *}$ & 0.007241 & CARE is effective \\
Jakarta Capital Province & $1687^{* * *}$ & $<2.2 \times 10^{-16}$ & CARE is effective \\
West Java & $7006^{* * *}$ & $7.124 \times 10^{-15}$ & CARE is effective \\
Central Java & $8217^{* * *}$ & 0.00318 & CARE is effective \\
Yogyakarta Special Region & $1208^{* *}$ & 0.04097 & CARE is effective \\
East Java & $8837^{* *}$ & 0.01415 & CARE is effective \\
Bali & 1644 & $\approx 1$ & CARE is not effective \\
\hline${ }^{* *}$ Significant with the test rate of $5 \%,{ }^{* *}$ Significant with the test rate of $1 \%$, CARE: Community Activity \\
Restriction Enforcement.
\end{tabular}

The LSSR and CARE policies are options to mitigate risk factors under social health emergencies. Other options include home, areal, and hospital quarantines. The steps taken must be based on epidemiological conditions, the magnitude of threats, effectivity, resource support, operational techniques, security, etc. The 2020 LSSR is described as the limitation of certain social activities in an area that is suspected to be infected/contaminated with diseases to prevent its spread/contamination. Article 59 of the Health Quarantine Law states that LSSR must at least include the closing of schools and workplaces as well as the limitation of religious and/or public activities. The law on LSSR states that with the approval of the Ministry of Health, the regional governments implement LSSR or limit the movement of people and items to a province or a certain city/regency. This implies the centralized authority in making LSSR-related policies as the regional government require approval from the ministry.

LSSR's implementation is ineffective due to the suboptimum role of the Covid-19 task force. This causes some problems, for instance, issues in the distribution of hazmats, lack of physical distancing despite the work from home policy, there are crowdings everywhere, thousands of people travel from one province to another, etc., even though the LSSR policy has been issued for a week. Thus, the military force must totally be involved, as argued by Willy Aditya, a legislative member [2] as law enforcement is key. 
President Joko Widodo (Jokowi) stated that no areal quarantine will be carried out as it greatly impacts society. During the implementation of the LSSR, central and regional governments coordinate to prepare isolation areas for those who travelled to other cities to prevent from infecting their families [3]. Jokowi stated that society complain about the policies as they affected their economy, but the government does not have many choices. Before this, the COVID-19 mitigation was limited to suggestions, that are in reality ignored by society. With LSSR, these regulations turn into obligations and prohibitions with stronger enforcement. Even so, such policies should not ignore society's economic and psychological conditions.

The determination of COVID-19 as a disease that causes Social Health Emergency implies the enforcement of criminal laws. Those who disobey the implementation of LSSR and CARE are imposed with criminal sanctions. This becomes problematic when the social distancing during these programs is only in the form of suggestions. Article 93 of the Law on Health Quarantine stipulates that those who disobey or disturb the establishment of health quarantines (in this case the LSSR and CARE) thus causing Social Health Emergency must be imprisoned with the maximum imprisonment period of a year and/or the maximum fine of Rp. 100,000,000,00 (a hundred million rupiah).

People disregard LSSR violations as criminal actions as there is a lack of strict law enforcement. There need to be strict sanctions to LSSR and CARE violators to create discipline [1]. Even so, legal enforcement should be preceded with persuasive and humane approaches.

In various literatures on emergency state administration laws, such restrictions are part of the state that has coercing and monopolizing characteristics. Just as Leviathan stated by Thomas Hobbes, the LSSR and CARE policies are a positive state authority, as it is for the public interest. It is state protection to society to prevent the spread of the disease. The state must provide correct and unpoliticized facts on Covid-19 [4].

The description of the legal policies above often happens in a legal state. It is based on the legal policy that aims to benefit society. There was a policy to free inmates whose imprisonment period is almost over to save them from the pandemic and imprisoning those who make crowds seem to be a normal thing, though it is rather confusing. But according to the theory of legal politics, both are an effort to achieve good regulations based on a particular condition [5]. The policy to punish violators of law that were formerly not prohibited is called Penal Policy. As stated by Arief, it is a criminalization policy that determines an action that was formerly not a criminal activity into a criminal one [6].

Another anomaly policy is the Ministry of Law and Human Rights to free thousands of inmates through assimilation and integration programs to prevent the spread of Covid-19 in prisons, juvenile correctional centers, and correctional institutions based on the Decision of Minister No. M.HH19.PK.01.04.04 of 2020. The Decision of the Minister of Law and Human Rights No. 10 of 2020 regulated the requirements for these assimilation and integration rights [7].

Society is against this problematic policy, considering that the release of thousands of inmates may drastically increase crimes. They think that the inmates are already safe in prison. Ironically, society must instead stay at home during LSSR. It is an anecdote that people who leave the house may be imprisoned but the inmates are released. This anomaly makes people disregard LSSR as they believe that if imprisoned, they will soon be released.

The weak LSSR policy enforcement becomes a consideration in applying CARE. The LSSR policy is unsuccessful due to a lack of enforcement. Mahendra suggests that the policy is not aimed to limit the COVID-19 infections, but is to prevent economic collapse. The government does not apply areal quarantine as it is difficult to fulfill the needs of Indonesians such as groceries, electricity, and water, where there are 14 million people in Jakarta alone. The areal quarantine will bring financial losses and even chaos. The government actually faces economic problems; thus, it applies the LSSR instead [8]. The unclear LSSR implementation increases the COVID-19 positive cases by tens of thousands of people.

Seeing the facts above, Indonesia may face a deceleration of the climax pandemic, meaning that there is a lengthening of the pandemic period due to a lack of areal quarantine. This may make all areas in Indonesia slowly become Red Zones. Society's nonconformity by leaving houses, not wearing masks, and crowding will increase the Covid-19 infections [9].

Different from the LSSR, the CARE policy was implemented rather strictly, though it caused economic issues. The Figure 1 shows the number of COVID-19 infections before the CARE policy was implemented, especially from June to July 2021.

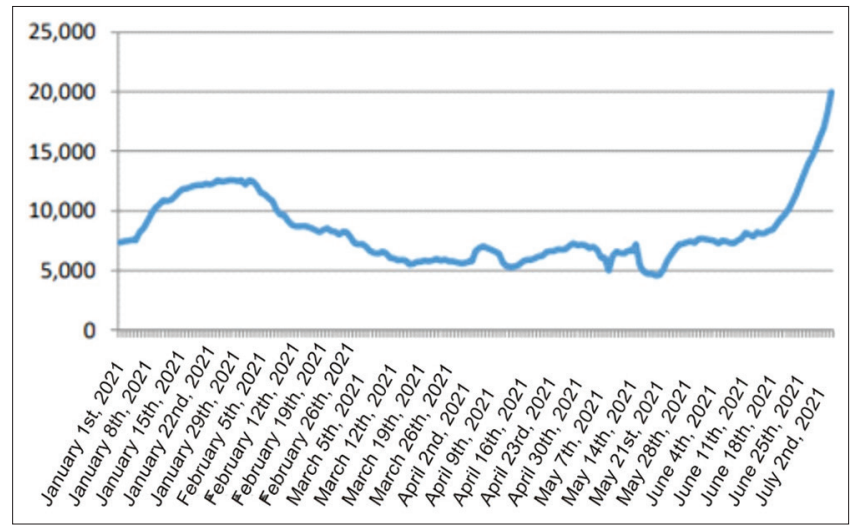

Figure 1: The number of COVID-19 sufferers [10]

The figure above shows that there are 100,000 cases of Covid-19 weekly from January to 
May 2021. There was a steep increase in July 2021. This condition was worsened by the fact that the Bed Occupancy Rate (BOR) for COVID-19 patients in Indonesia reached $70 \%$ on July 2, 2021 [10], [11]. The increase of the BOR is simultaneous with the increase of COVID-19-related deaths. The Ministry of Health noted that there were 100,000 deaths weekly since June 29, 2021 [11].

To prevent the increase of COVID-19 cases, the government implemented the Emergency CARE policy. The Emergency CARE consisted of four levels, with Level 1 as the level that indicates the safest condition. The Emergency CARE was implemented in all cities and regencies in Java and Bali islands with pandemic assessment situations from July 3 to July 20, 2021. The level-3 and level-4 Emergency CARE was extended to August $30^{\text {th }}, 2021$.

Some Emergency CARE policies limit teaching and learning activities, non-essential and essential sectors, eating and drinking in public areas, places of worship, transportation, and other activities that produce crowds. Society must comply with the public health protocol, namely wearing masks, washing hands, physical distancing, avoiding crowds, and decreasing mobility. This is the active participation of society to prevent the spread of the Covid-19 [12].

According to Intermountain Healthcare as quoted by Yakhamid and Zaqi, wearing masks may decrease the risk of being infected by COVID-19 by $98.5 \%$. It is necessary to maintain distances to decrease the risk of being infected. When conversing and coughing, droplets may reach $2 \mathrm{~m}$. Then, when someone sneezes, the droplets may reach $6 \mathrm{~m}$. According to Beale et al., washing hands with soap or hand sanitizers may decrease the risk of COVID-19 infection by $35 \%$ [13].

Yakhamid and Zaqi [13] carried out a research on the effectivity of the CARE program in decreasing COVID-19 cases. Their testing resulted to a p-value with a significance rate of $5 \%$. Thus, it is concluded that the average confirmed COVID-19 cases per 100,000 people weekly in Java and Bali decreased during CARE. Thus, the CARE policy is one of the effective strategies in decreasing the number of Covid-19 positive cases in these islands. To know when the decrease starts, Yakhamid and Zaqi carried out a Wilcoxon test (Table 1).

Then, Yakhamid and Zaqi carried out a Shappiro Wilk test to know if the data is normally distributed (Table 2). The results of that test yield the result that most provinces that will be tested have the smallest sample size $(n<30)$ and that are not normally distributed. Thus, a non-parametric Page test is carried out to see the difference of the average cases inter-time reference. The Page test is carried out using a linear alternative hypothesis, namely the decrease of the average COVID-19 cases during the Emergency CARE, namely, from July to August 2021.

\section{Discussion}

The results above show that the Covid-19 confirmed cases per 100,000 people/weekareabnormal. It has a positive skewness, showing that some cities/ regencies have higher confirmed cases compared to other cities/regencies in general. At the first 4 weeks of the Emergency CARE policy, there was not yet a significant decrease of confirmed COVID-19 cases per 100,000 people/week. This showed that its application is not yet effective in decreasing the number of cases in Java and Bali islands from July 2 to July 30 , 2021. Thus, it was extended. The decrease of the COVID-19 cases only started in the $5^{\text {th }}$ week of the Emergency CARE after its extension. The CARE's effectivity may be seen aggregately and even partially at every city/regency. During its implementation, some cities/regencies succeeded or failed in decreasing the confirmed COVID-19 cases per 100,000 people/ week in Java and Bali Islands from July 2 to August 27, 2021 [14].

\section{Conclusion}

The LSSR policy in 2020 was not effective in decreasing the number of COVID-19 cases, as it lacked implementation clarity. It means that the sanctions and monitoring were not implemented well. The LSSR policy was created terribly without concept. Thus, its implementation failed to decrease COVID-19 cases. This is different from the CARE policy that had detailed concepts and clear enforcement. Based on the analysis carried out, it can be concluded that in general, the Emergency CARE in Java and Bali Islands that was implemented up to August 27, 2021, was effective in decreasing the number of COVID-19 positive cases per 100,000 people/week.

\section{References}

1. Hairi PJ. Implication of the large-scale social restrictions to prevent COVID-19. Info. 2020;7(1):4-7.

2. Fajar Indonesia. The Legislative House Demands the Indonesian Military Force to Totally be Involved: The Large-Scale Social Restrictions is Suboptimum; 2020. Available from: https://www. fin.co.id [Last accessed on 2020 Apr 07].

3. CNBC Indonesia. This is Why Jokowi Does Not Want to Quarantine the Indonesian Territory; 2020. Available from: https://www.cnbcindonesia.com/news/20200402091127-4149230/catat-ya-ini-Iho-alasan-jokowi-takmau-karantinawilayah-ri [Last accessed on $2020 \mathrm{Apr}$ 04].

4. Noviantoro R, Michael T. Implementation of the Large-Scale Social Restrictions Law: Obey Leviathan. Available from: https:// 
www.mediaondonesia.com [Last accessed on 2020 Apr 11]

5. Sudarto S. The Law and the Criminal Law. Bandung: Alumni; 1981. p. 79.

6. Arief BN. Cybercrime and the Development of Cybercrime Analyses in Indonesia. Jakarta: Raja Grafindo Persada; 2006. p. 155.

7. Yunus NR. COVID-19 policy: Freeing prisoners and prisoning large-scale social restriction violators. Adalah. 2020;4(1):8.

8. Budiono A, Iriani D, Safira ME, Roihanah R, Noor M, Khasanah $\mathrm{NU}$, et al. Legal protection of vaccine administration health service to prevent the spread of the coronavirus disease 2019 in Indonesia. Open Access Maced J Med Sci. 2021;9(E):1050-4.

9. Wardiono K, Dimyati K, Nugroho SS, Nugroho H, Acob JR, Budiono A. Philosophy, law, and ethics of handling COVID19 pandemic in Indonesia. Open Access Maced J Med Sci. 2022;9(E):1104-8.

10. COVID-19 Task Force. Monitoring the Compliance of NationalLevel Health Protocols; 2021. Available from: https://www. covid19.go.id [Last accessed on 2021 Aug 22].

11. Ministry of Health. Recap of COVID Hospital Beds; 2021. Available from: https://www.kemkes.go.id/downloads/ resources/download/ketersediaan-tempat-tidur-rscovid19/borrs-2-juli-2021.pdf [Last accessed on 2021 Jul 03].

12. Ministry of Internal Affairs. Ministry of Internal Affairs Instruction No. 35 of 2021 on the Corona Virus Disease 2019 Large-Scale Social Restrictions Level 4, Level 3, and Level 2 in Java and Bali. Jakarta: Mendagri; 2021.

13. Yakhamid RY, Zaqi NA. Effectivity of Emergency Large-Scale Social Restrictions to Handle the Increase of COVID-19 Cases. Case Study of 128 Cities/Regencies. Official Statistics. Jakarta: STIS; 2021. p. 237.

14. COVID-19 Task Force. Handling the COVID-19 with 3M, 3T, Vaccination, Discipline, Integrity, and Consistency. Jakarta: Satgas COVID-19; 2021. 